\title{
Erratum to: Gender Differences in Financial Education: Evidence from Primary School
}

\author{
Flavia Coda Moscarola ${ }^{1,2} \cdot$ Matteo Migheli $^{1,2}$
}

Published online: 15 September 2017

(C) Springer Science+Business Media, LLC 2017

\section{Erratum to: De Economist (2017) 165:321-347 DOI 10.1007/s10645-017-9300-0}

In the original publication of the article, order of authors in the author group was incorrectly published and the corresponding author's e-mail address was not included.

The corrected author group and the corresponding author e-mail address are given in this erratum.

The online version of the original article can be found under doi:10.1007/s10645-017-9300-0.

Flavia Coda Moscarola

flavia.codamoscarola@carloalberto.org

Matteo Migheli

matteo.migheli@unito.it

1 Department of Economics and Statistics "Cognetti de Martiis", Università degli Studi di Torino, Turin, Italy

2 CeRP - Collegio Carlo Alberto, Moncalieri, Italy 